backs), and even baby elephants may fail to get up and so become separated from their mothers. At the same time heavy traffic on tourist-favoured roads frightens off the timid animals which may be forced into other areas less suitable to their needs - this is particularly true of eland and sable which will shun tourist areas even to the extent of leaving the park. Dr Pienaar concludes that whether the effects of road building are beneficial or detrimental they are certainly profound, and park roads should only be built in close co-operation with the conservation staff.

The East African Wild Life Society, according to Africana, is becoming increasingly alarmed at the enormous number of leopard skins and articles made from the skin on sale in Nairobi shops. In 1967 more than 1000 leopard skins are known to have been

Leopard Skins Legal and IIIegal imported into Kenya; what is not known is where they came from, though it may not be difficult to guess. But on the last page of the same issue of Africana, are several advertisements for skin goods including one illustrating a leopard skin handbag. The problem is, of course, to distinguish between the legal and the illegal skins. Uganda at least makes a start by prohibiting all leopard skin imports. In the USA the WWF is running a campaign to persuade women and furriers to help halt the extermination of the spotted cats, urging them to 'change a destructive fashion trend' by renouncing 'the wearing and use of leopard, cheetah, ocelot and jaguar', and by urging department stores and furriers to stop selling the furs. Results so far include a lot of press, radio and television publicity and a decision by two of America's leading fur designers to stop selling leopard and cheetah coats.

\title{
Appeal for Linnean Collections
}

CONSERVATION is ultimately based on the work of naturalists, biologists and systematists in the museum, the laboratory and the field, for only they can provide the essential basis of facts about the life history and ecology of animals and plants needed to implement an effective conservation policy. Taxonomy, the science of the classification and naming of organisms, is the most basic of all disciplines, for until you know exactly what animal or plant you are dealing with, it is fruitless to attempt any conservation measures. The news that the Linnean Society of London is appealing for $£ 55,000$ to preserve and develop its collections is therefore of more than academic interest to conservationists.

The unique collections of the great Swedish naturalist Linnaeus, father of modern scientific nomenclature, are still housed in the cabinets in which they were acquired over a hundred years ago. They are therefore subject to considerable risk, and if they are not housed in the special room now planned in the basement of Burlington House, with protection against fire and flood and some control of humidity and temperature, either they may eventually be lost or their utility may be gravely impaired.

Such a loss would not just be a sorrow for antiquarians, but would 
gravely affect systematists of many groups of animals and plants, who may still be obliged to examine Linnaeus's exact specimens in order to be quite certain of the identity of an animal or plant to which a particular name is attached. Last year 55 biologists from 14 different countries came to examine the Linnean collections in situ, and on a further 16 occasions specimens were sent for study to the British Museum (Natural History) or the Royal Botanic Gardens at Kew. In the past 20 years the collections have been consulted some 1200 times by research workers from 45 countries; some 60-70 queries are dealt with by correspondence each year. The provision of more space for the library and the preparation of a new catalogue, both among the developments planned when the appeal is completed, will also greatly benefit research workers and conservationists throughout the world. There is every reason therefore to appeal with confidence to members of the FPS and other readers of ORYX to help the Linnean Society meet its target of $£ 55,000$.

RICHARD FITTER

\section{Sightings of Cyprian Mouflon}

MR B. GARVEY writes that he made six visits to the Paphos Forest in northMest Cyprus in search of the Cyprian mouflon between July 1967 and March 1968. The first three visits he saw nothing but the remains of one male; on the fourth, in the Ayia area, he saw three rams and two ewes; on the fifth, camping over Christmas in the same area he saw between nine and twelve animals on the 23rd, and on Christmas Day, when the party split up, five ewes were seen on a ledge leading to Trypylos Peak, a pair of horns measuring 24t inches along the front edge was found, and one ram and two ewes seen on the road between Ayia and Stavros Tis Psokas Forest Station; the sixth visit produced five rams on a spur south-east of Milikouri. The Cyprus Government which signed an 'Acceptance of Ultimate Responsibility' certificate from the Survival Service Commission of IUCN, (reproduced about half-size in ORYX, December 1967) does its best to protect the mouflon. In 1964 it was estimated that the mouflon's numbers were down to between two and three hundred.

\section{New Threat to Whooping Cranes}

THE winter feeding grounds of the whooping cranes are included in the area on the eastern shore of the Aransas Wildlife Refuge where the Texas Parks and Wildlife Commission has given permission for shell dredging. In this destructive and disturbing operation the dredger rips the oyster shell deposits from the sea bottom (for road building) taking plant and animal life with it, and sending a cloud of smothering silt over the surrounding underwater area that kills the food supply of fish and other wildlife. The effect on the cranes is yet to be seen.

\section{The Little Crooked Stream}

UNDER a new Stream Preservation Law in Montana, USA, the Fish and Game Department requires that every foot of a stream lost in straightening operations for road-making shall be compensated for by the digging of an equal length of crookedness. 'If a creek is four miles long before road work', said an enforcement officer, 'it must be four miles when the contractor is through.' The department believes that firm enforcement of this law will keep destructive operations to a minimum. 